probably its author himsclf could have wished. A wrong impression of the subject is created by the title, which though singularly happy in itself does not fairly describe the contents of the book. Such a title suggests an accurate and luminous discussion of the phenomena of evaporation and condensation, the growth and movements and disappearances of mists and clouds, the formation and distribution of rain and the laws regulating the rainfall over the globe, the meaning of frost, the birth and history of hail and snow, the circulation of water over the land with the ways and workings of brook, stream, and river, from mountain-peak to sea-shore, the architecture and the functions of snow-fields, glaciers, and icebergs-in short a kind of scientific poem, dedicated to the glory of that grand old element-water. Dr. Tyndall could write such a poem better than most men, and indeed it was with the expectation that he had attempted it that we opened this last volume of his. Out of the 192 pages 28 are devoted to clouds, rains, rivers, waves of light and heat, oceanic distillation and mountain condensers. The rest treat wholly of ice. So that if we may judge by the relative space devoted to the different forms of water, ice must be six times more important than all the rest put together. A less ambitious title, such as its author could readily suggest, descriptive of the fact that the book is a record of work, intellectual and corporeal, among the Swiss glaciers, would prevent the feeling of disappointment with which many a reader has no doubt come to the last page.

Dr. Tyndall did not intend, we suppose, that his book should be regarded in any other light than as a popular exposition of his subject, and would probably disclaim any place for it as a contribution of new facts and reasonings to our knowledge of glaciers. His narratives of lasi year's climbings and observations read very much like those of older ones with which he lias already made us familiar. They are pleasantly written, and will convey to a reader, who has never seen a glacier, a picturesque notion of what he has missed. But surely it was not necessary to rake up again the Forbes-Rendu controversy, nor to renew the claims of Agassiz and Guyot. We could have wished, too, that while alluding to $\mathrm{Mr}$. Mathews and other recent obscrvers on ice-structure the writer had taken some notice of the attack upon his own theory by Canon Mosely and Mr. Croll.

\section{OUR BOOK SHELF}

Die Anwendung Des Spectralapparate von Dr. $K$. Vierordt. (Tübingen: H. Laupp, I873.)

DR. VIERORDT has been endeavouring to found a quantitative spectrum analysis for bodies giving an absorption spectrum. His method consists in the use of a slit divided horizontally into two parts; one of these is adjusted to a certain width; the solution whose absorption is to be examined is placed opposite this, and in front of the other half is placed another solution of the same body but of a different strength, and the slit is then narrowed or widened as the solution is stronger or weaker until the absorption is the same in both halves of the spectrum. The width of the latter slit is then read off. By using a number of solutions of strengths varying decimally from the weakest possible to the strongest through which light will pass, curves are obtained and a solution of unknown strength can then be interpolated in the curve and its value ascertained. The solutions to be examined are, of of course, kept at a constant thickness. As the relation between the concentration of the solution and its coefficient of the absorption of light only remains constant within certain limits, solutions of the necessary dilution have to be employed and unknown solutions must be diluted to this point: the value is then found by calculation.

Tables for calculations of various kinds required are given, and the memoir is illustrated with lithographs of the working details of the divided slit. A number of specimen curves are also given. The memoir is well worthy the attention of all who have to estimate the strength of colouring matter.

\section{LETTERS TO THE EDITOR}

[The Editor does not hold himself responsible for opinions expressed by his correspondents. No notice is taken of anonymous communications.]

\section{Existence of Man in the Miocene}

I HAVE received a letter from $\mathrm{Mr}$. Edmund Calvert, in which he informs me that his brother, Mr. Frank Calvert, has recently discovered, near the Dardanelles, what he regards as conclusive evidence of the existence of man during the Mlocene period. Mr. Calvert had previously sent me some drawings of bones and shells from the strata in question, which Mr. Busk and Mr. Gwyn Jeffreys were good enough to examine for me. He has now met with a fragment of a bone, probably belonging either to the Dinotherium or a Mastodon, on the convex side of which is engraved a representation of a horned quadruped, "with arched neck, lozenge-shaped chest, long body, straight fore legs, and broad feet." There are also, he says, traces of seven or eight other figures, which, however, are nearly obliterated. $\mathrm{He}$ informs me that in the same stratum he has also found a flint fluke, and several bones broken as if for the extraction of marrow.

This disc jvery would not only prove the existence of man in Miocene times, but of man who bad already made some progr: ss, at least, in art. Mr. Calvert assures me that he feels no dosbt whatever as to the geological age of the stratum from which these specimens were obiained.

Of course $I$ am not in a position myself to express any opinion on the subject; but I am sure that the statements of so compe. tent an observer as $\mathrm{Mr}$. Colvert will interest your readers.

High Elns, March 23

JOHN LUBBOCK

\section{Adaptation to External Conditions}

TIE curious modification of adaptation to external conditions in the case of the Salcumandra atra, which I have more than once brousht under the notice of naturalists, but which I myself first noticed under the direction of Prof. von Siebold, has been cited by Mr. Darwin ("Origin of Species," 4th Ed. p. 534) in confirmation of his views. I revert to it now for the sake of its illustration of a new and striking observation, which has excited the increảulity of several eminent naturalists in France-an incredulity, we may suppose, founded on their ignorance of the previous observation. The fact to which I called attention was this: The ordinary salamander, or Newt, is born in the water as a tadpole, and in the water it completes its metamorphosis. But the Salamanara atra, living high up in the mountains, with no pools in which to pass its tadpole existence, is born on the land, a completely formed animal; that is to say it passes through the tadpole stage while still within its mother's body. I have taken it from the gravid female in this tadpole state, and placed it in water, wherein it swam as if that were its natal ele. ment

In the Revue Scientifique, No. 37, there has just appeared a brief account of some observations made by $M$. Bavay at Guadeloupe, from which it appears that the frogs, having in that vol. canic island no marshes nor pools suitable for the early tadpoles, have adapted themselves to these conditions by passing through 